\title{
ORGANIZATIONAL CITIZENSHIP BEHAVIOR ROLE IN MEDIATING THE EFFECT OF TRANSFORMATIONAL LEADERSHIP ON ORGANIZATIONAL PERFORMANCE IN GOLD INDUSTRY OF SAUDI ARABIA
}

\author{
Aref Abdulkarem Ali ALHASHEDI ${ }^{1 *}$, Barjoyai BARDAI ${ }^{2}$, \\ Maged M. Mahyoub AL-DUBAI ${ }^{3,}{ }^{\text {, }}$, Mohammed Abdulrazzaq ALAGHBARI ${ }^{4}$ \\ ${ }^{1}$ Al-Madinah International University, Kuala Lumpur, Malaysia \\ ${ }^{2}$ Department of Economics and Management, Al-Madinah International University, Kuala Lumpur, Malaysia \\ ${ }^{3}$ Management Development Institute of Singapore in Tashkent, Uzbekistan \\ ${ }^{4}$ Business Administration Department, Applied Science University, Bahrain
}

Received 20 May 2020; accepted 27 July 2020

\begin{abstract}
This paper mainly aims at investigating the mediating effect of organizational citizenship behaviour in the relationship between transformational leadership behaviour and organizational performance as well as the mediating effect of organizational citizenship behaviour in the relationship between psychological ownership, working environment, employee involvement, incentives, and employee motivation, and organizational performance. To achieve the objectives of the study, quantitative research approach was applied through a questionnaire specifically designed to collect primary information from the samples of the study, which consisted of (250) managers in gold shops in Jaddah. The collected data was analysed using SPSS 20.0 and Smart-PLS 3. The results showed that organization citizenship behaviour mediates the relationship between transformational leadership behaviour, psychological ownership and incentives, and organizational performance in the Saudi Arabian gold industry. Also, organization citizenship behaviour has no mediating effect on the relationship between working environment, employee involvement, employee motivation, and organizational performance in the Saudi Arabian gold industry. At the end of this study, the researcher recommended the need to encouraging the practice of organizational citizenship behaviours by developing a set of special regulations and instructions, and consider organizational citizenship behaviours as one of the important criteria in the annual performance appraisal models for employees, in addition to that, the quantitative method was adopted in this research to test research hypotheses, thus, future studies can rely on other methods qualitative or case study to verify the results of this research.
\end{abstract}

Keywords: organizational citizenship behaviour, transformational leadership, organizational performance, gold industry.

JEL Classification: C12, O43.

\section{Introduction}

In light of the rapid developments in business organizations today, the increase in the complexities in the business environment in all its aspects, the need for change at all levels of work, and the increase in the effectiveness of the relationship between the leader and the subordinates, it was necessary to think about creating more appropriate leadership styles, as transformational leadership was the most important of these patterns, which it is one of the modern concepts in management thought. Institutions today need leaders who are able to form a clear future vision for institutions, strategic planning in developing and managing change, and avoiding crises, to keep pace with modern developments and trends in information and communication technology (Guan \& Frenkel, 2018). One of the managerial concepts recently produced by contemporary management thought that has attracted the interest of researchers and practitioners alike is the concept of organizational citizenship behaviour (Khosravizadeh et al., 2017). The various consequences of organizational citizenship behavior confirm the role that such behavior plays for both the individual and the organization. This is reflected in the individual's personal life, therefore directly will decrease the performance of the individual, and finally will negatively affect organizational performance (Shanker, 2018). Many studies have shown that the successful organizations are those that care about employee

*Corresponding author. E-mail: arefalhashedi@gmail.com 
issues, because it is considered as its most important capital investment for managing current and future challenges, so a transformational leaders exhibit certain behaviors to motivate their employees to achieve organizational objectives. Furthermore, continuous performance is required due to its importance for improvement and progress (Shahin et al., 2014). Also, researches especially focus on the scope of organization citizenship behaviours, factors which cause this behaviours, and effects of it on employees and organization (ALHussain, 2011).

The gold industry is one of the most developed and growing industries in the past few decades, and has been the force behind dramatic economic growth in Saudi Arabia. As it stiffs intensive competition on the domestic and international level, as companies experienced many challenges that necessitate the use of modern means, mechanisms and strategies, in order to comply with new phenomena that emerge for the long run. Saudi Arabia is well-known as No. 1 in Gulf Arab regarding trading gold and jewellery; in fact, gold has a great root in the culture of the people who live there. Thus, gold industry is considered very significant in Saudi Arabia (WGC, 2011). The importance of the gold industry has increased and developed in the modern era, as gold has a great value in appearance and economy. The decline and rise in gold price significantly affects the economies of countries. The recent rise in gold prices has led to a decline in the movement of buying and selling, which led to a drop in demand for gold, which led to a decline in the industrial rate remarkably (Ali, 2009). According to WGC (2014), among the top 40 countries in the world, Saudi Arabia is one of the largest markets for gold. It traded over $\$ 8$ billion worth of gold each year. However, the research has also shown that the management system of the Gulf area, especially Saudi Arabia needs some enhancement and improvement (Ali, 2009). Accordingly the Makkah Chamber of Commerce showed that 1.500 retail shops were shut down due to some reasons including management system in October 2012 (Saudi Mining \& Minerals, 2015).

Although there is a large body of research related to transformational leadership behaviour and organization citizenship behaviours in western context, these studies are scarce in the Arabian countries Such as Saudi Arabia (AlKindy et al., 2016). The real problem is that there are quite number of challenges and issues facing gold industry in Saudi Arabia, these challenges cover the area of transformational leadership, organizational citizenship behaviour, working environment, and employee motivation as a result of the wide-ranging change in scope of globalization and its mechanisms (Cichorzewska \& Rakowska, 2017). In light of the above, it is clear that the role of company's' manager is not only to provide the necessary manpower with competence and specialization, but also to carry out many important tasks and responsibilities such as strategic planning, employee involvement, evaluating employees' performance, and occupational safety. So there are many of issues to be handled carefully and seriously, which have a negative impact on organizational performance such as weakness in enhancing psychological ownership of employees, bad working environment, biased behaviour in incentives, promotion and selection, and occupational safety (Muthike, 2016). Regarding investigating the factors that can enhance the organizational performance, this research aims mainly to answer if organization citizenship behavior can mediate the relationship between transformational leadership behavior and organizational performance. In addition to the mediating effect of organizational citizenship behaviour in the relationship between psychological ownership, working environment, employee involvement, incentives, and employee motivation, and organizational performance. This study was limited to gold shops in Jaddah, and therefore the generalization will be confined to these companies. In addition, this type of research, which is based on the opinion of a sample may be a source of error, as the statistical analysis depends on their responses towards research variables.

\section{Literature review}

This section reviews research variables in detail, including transformational leadership behavior, psychological ownership, working environment, employee involvement, incentives, employee motivation, organizational citizenship behavior and organizational performance.

\subsection{Transformational leadership behaviour}

Transformational leadership behavior is a form of leadership that improves task and contextual performance behaviours (AlKindy et al., 2016). Brandt and Laiho (2013) illustrated that transformational leadership are likely to affect workers more optimistically. While leaders drive and initiate the change of organization; they run the change only with the assistance of other transformation agents, these transformational agents work with different competencies and skills that are changed based on exacting circumstances and requirements. The influence of transformational leadership on subordinates are explained in three leadership results such as the leader ability to create additional effort on the element of those being led, the perception of subordinates of leader efficiency, and their satisfaction with the leader. Also, transformational leaders would be predictable to magnetize in unprincipled practices, and the judgments of the ethical posture of a leader may play a strong role in affecting the satisfaction of followers with their leader (Alqatawenah, 2018).

Soane et al. (2015) explained that efficient transformational leadership style is the major cause of competitive benefits for any type of organization. Leaders are granted the opportunity to guide, because they are accepted and perceived by followers that they lead like leaders and not because they are selected by superior managers. Actually, a leader is accountable for not only leading but also equipping followers with the devices that are required to achieve the goals of organization. In the occasion that a 
leader does not have the ability to present the adequate resources or information that is demanded, a disagreement might arise steadfast in de-motivation and distrust. And as a result of that the role of leader is very exact and each decision or action must be very strategic. Leaders can foresee future likelihoods and map substitution strategies in order to meet uncertainties. Such traits are widespread in chronological leaders. This sense of expectation is supposed to be not learned so it should be innate (Jun, 2017).

\subsection{Psychological ownership}

Psychological ownership is the feeling that is generated and formed by employees towards the job they perform (Ruganzi, 2017). The researcher believes that the individuals' sense of psychological ownership towards work drives them to continuously strive for development in the organization in which they work (Liu et al., 2017). In addition, psychological ownership is a positive resource that can be measured, developed and invested to achieve organizational competitive advantages and effective performance. At the organizational level, psychological ownership can be created through one of the three main stages that are: controlling the goal, gaining in-depth knowledge of the goal, or investing in the goal, which means when individuals are able to deal with the goal (Kvitne, 2017). This means that when individuals are able to better deal with the goal, recognize it and devote more effort to improving the goal, they are likely to experience higher levels of psychological ownership (Campbell Pickford et al., 2016). Psychological property reflects a state of individual consciousness, thoughts, and beliefs. Ahmad and Zafar (2018) examined impact of psychological ownership on organizational citizenship behavior among employees. The results showed a high level of psychological ownership and organizational citizenship behaviour. It was also found that there is an effect of psychological ownership on organizational citizenship behaviour, and did not show differences due to personal variables. The study also showed that organizational citizenship behaviour and mutual trust between employees and their direct supervisors directly affect the level of performance of workers. Fogec (2017) examined how organization-based psychological ownership emerges from control over work via job-based psychological ownership.

\subsection{Working environment}

Work environment plays a key role in improving organizational performance (Massoudi \& Hamdi, 2017). All organizations seek to create an excellent and attractive work environment for their employees which leads to support the national economy, for instance, employee who works in a good environment has the ability to cope better with economic shocks and to deal efficiently with the current changes, so this helps institutions fulfil rapid economic growth rates and achieve sustainable development goals. Work environment consists of a set of factors that have a effect on the workers within their environment. This effect may be either positive or negative in their performance (Agbozo et al., 2017). In order to create a stimulating and motivating work environment that enhances the concept of loyalty, new management visions should take into consideration the problems and concerns of employees and communication in the workplace. The work environment consists of a set of variables that have a direct or indirect effect on employees within their surroundings. This effect may be either positive or negative in their performance. The working environment is the main means of improving performance and increasing employee productivity, which reflects their loyalty and satisfaction with the organization (Prabhakar, 2016). This depends on what employees see according to their perceptions and that vary from one to another. Active management is keen to identify these factors and their relationship to other variables, which contributes to access to an ideal working environment through which organizational performance are achieved (Bari et al., 2013). Therefore, these are some things must be taken into consideration, related to benefits of giving an atmosphere of mental comfort, which motivate employees to innovate and deliver effectively such as managers should not be late to express their appreciation to their employees because the longer the period between giving thanks and work, the less the impact of that on the employee (Amoatemaa \& Kyeremeh, 2016).

\subsection{Employee involvement}

Employee involvement is leadership model that focuses on guidance to a leadership that believes in participation and consultation (PratimaSarangi \& Nayak, 2018). Employee satisfaction with involvement in decision-making does not necessarily guarantee improved performance and commitment. The potential for improvement in performance can be increased when there is a clear definition of the role of employee involvement in decision-making. In other words, employee involvement includes indulgence, contribution and responsibility. The application of employee involvement is through the development of goals and plans, participation in the development of alternatives, the evaluation of results, and cooperation in solving problems, as the lack of eligibility and experience of employees to involve effectively can lead to confusing, frustrating and unexpected roles (Chandani et al., 2016). It is therefore necessary to have clarity on the role and level of need for employee involvement in the front lines so that they can be enabled to respond directly to employee's needs (Lazauskaite-Zabielske et al., 2018).

\subsection{Incentives}

Incentives refer to an anything that can attract an employee's attention and motivate them to work, which enhances the overall organizational performance (Chepkemoi, 2018). Accordingly, it is important for the individual to be able to work, but the most important thing is to be 
enthusiastic and willing to do the work. Therefore, interest in motivating workers and creating a desire for effective cooperative work has increased so as to ensure the economic achievement of the goals of the organization. In addition, incentives affect the performance of workers in a positive way, often, because of the happy impressions they reflect, especially when they feel that the work they are doing has been appreciated. The system of incentives is used as a motivational tool to encourage employees to improve their performance, as incentives are technique which motivate behaviour, and which can be used by the managers in the form of rewards or penalties to compensate for the problems arising by conflicting objectives and decentralized information and to obtain the coveted behaviour (Raja et al., 2018). Therefore, the incentive system must be fair and therefore everyone has the right to an equal share of incentives as long as he has adhered to the specific rules and criteria. Also, non-financial incentives are considered as the most important tools to reward employees. It has been explained that about $70 \%$ of the managers use non-financial awards in their organizations (Tufail et al., 2017). Add to that, lacking fair rewards leads to decrease their performance, as employees therefore feel disloyal to the organization they work in as well as their lack of attention to the damage that the company may face (Alfandi \& Alkahsawneh, 2014).

\subsection{Employee motivation}

Employee motivation is the level of effort, commitment and energy that an organization's employees bring to their jobs (Kumari \& Thapliyal, 2017). Inspiration motivation behaviour supports leaders to inspire and motivate employees by providing a very challenging job. Researchers focus idealized influence behaviour as a part of charismatic leadership theory. In parallel, others describe combined idealized influence and inspirational motivation behaviours as charismatic leadership behaviour (Abusharbeh \& Nazzal, 2018). Motivation awakens the enthusiasm, motivation and desire to work among employees, which positively reflects on overall performance and increased productivity (Dobre, 2013). In addition, motivation works to prevent the employees' frustration and push them to persevere in their work and make it high efficiency (Pekaar et al., 2017). Furthermore, employee motivation contributes to the explosion of their abilities and energies, which reduce the size of the workforce required by the organization or management. This minimizes the costs incurred by the organization and also leads to the possibility of channelling the surplus human capacity to other organizations that may suffer from a shortage of workforce. This in turn helps to solve many of the problems faced by departments such as low production capacities, high rates of labour turnover, labour disputes and others (Rahmati \& Mohebi, 2016). Thus, motivation can make managers overcome many of the constraints they face. It is imperative that the motivational leadership provide, confidence, security and respect (Osisioma et al., 2012). According to Kurose (2013) motivation is the process of activating the reality of employees in positive or negative ways to enhance organizational performance.

\subsection{Organizational citizenship behaviour}

The subject of organizational citizenship behavior has received wide attention in the field of research during the past decades because of its significant impact on the success of the organization and its continuity in the competitive business environment. Organizational citizenship behavior contributes to reducing the organization's need to allocate scarce resources, maintaining the cohesion and unity of the organization, and helping employees to do their work by allocating more time to effective planning and problem solving (Hemaloshinee \& Nomahaza, 2017). Organizational citizenship behaviour describes a person's voluntary commitment within an organization that is not part of his or her contractual tasks. For example, helping others with heavy workloads, does not take extra breaks, and keep up with developments in the company (Dinka, 2018; Park, 2016). Organizational citizenship behaviour is indeterminate and is not officially linked to incentive and performance appraisal systems in organizations (Klotz et al., 2018). The focus of the concept revolves around the factor that is one of the most important organizational resources at all, since it cannot imagine the existence of any basis for the organization, because the human element is a fundamental pillar of development and progress in any society, as it is known that most developed countries have reached what It is an attic of prosperity and development in various fields due to the attention it has placed on its human resource (Cichorzewska \& Rakowska, 2017). Voluntary practices or organizational citizenship behaviours by leaders have direct implications for employee values, actions and behavior. In this regard, the transformational leader always motivates employees to do more than expected by acting as role models and caring for their needs, which maximizes the level of employee confidence. In this regard, employees were found to be engaged in voluntary practices when their confidence in their leader was high and vice versa. This kind of organizational citizenship behaviors not only does not increase organizational performance, but brings a lot of adverse effects, or even reduces organizational effectiveness (Kumari \& Thapliyal, 2017). Alqatawenah (2018) pointed out the importance of organizational citizenship behavior for individuals by providing creativity and innovation, developing ideas and proposals submitted by individuals, enhancing motivation for achievement and improving performance and a sense of responsibility towards the organization, and providing an opportunity for individuals to test their abilities and managerial ability through their contribution and participation in decision-making. Robescu and Iancu (2016) revealed that positive attitudes towards employers are linked to the emergence of organizational citizenship behaviours, but self-confidence has been instrumental in strengthening this relationship. 


\subsection{Organizational performance}

Organizations performance is the integrated system for the production of the organization's business (Cheema \& Asrar-ul-Haq, 2017). According to Chong and Law (2016), organizational performance includes seven dimensions that are creativeness, innovativeness, productivity, efficiency, effectiveness, competitiveness, and profitability. The organization's work system includes input and output elements with a range of information and analysis methods (Devi, 2017). The various activities within the organization are carried out and practiced in a correlation between inputs and outputs and work procedures using performance measures and analysis methods. Therefore, this determines the relations between the parties of the organization internally as well as between the organization and the surrounding environment externally (Huang et al., 2016). Outstanding performance is one that exceeds expectations for normal performance, and is attributable to both employee and leader efforts. It is a set of behaviors, abilities, and intellectual and cognitive skills enjoyed by individuals working in organizations, so that they have the ability to employ those skills, knowledge and behavior in their field and specialization (Kazimoto, 2016). This makes them work beyond the standards of the organization and outperform what others can do, and provide ideas and products characterized by modernity, originality, creativity and excellence, which promote the achievement of high-level objectives and the growing performance of the organization (Almarhoon et al., 2017; Campbell et al., 2016).

\section{Research problems and questions}

One of the most important challenges facing leaders nowadays is their ability to adapt to a continually changing global environment while at the same time continuing the dynamics of the organization. The style and type of leadership active plays a main role in the successful achievement of their responsibilities and the overall success of their organizations. Leadership manifests itself through different leadership styles (Mildred, 2016). Accordingly, organizations cannot continue to progress without having good citizenship behaviour which foster the relationship between transformational leadership behaviour and organizational performance as well as organizations should work to understand the point that they are the most valuable assets of organization (Shahin et al., 2014). Employees in Saudi Arabia complain about the lack of incentives, whether financial or non-financial, as well as the unfair distribution of rewards among employees, as there is a state of dissatisfaction prevails among employees regarding the incentive system practiced in their companies, both material and moral (Jehanzeb et al., 2012). Furthermore, there is a deficiency in the systems and methods of incentives applied to employees, which affects their survival in the company (Shahin et al., 2014). Furthermore, most leaders and managers suffer from poor ability to manage the emotional and psychological side of employees in the work environment. Neglecting the impact of the emotional side on the work environment is the main reason for leaving employees to work in a particular company, even if their salaries are high (Potdar et al., 2018).

Based on that, the researcher raises the following questions:

1. To which extent can organization citizenship behaviour mediate the relationship between transformational leadership behaviour and organizational performance in the context of gold industry in Saudi Arabia?

2. To which extent can organization citizenship behaviour mediate the relationship between psychological ownership and organizational performance in the context of gold industry in Saudi Arabia?

3. To which extent can organization citizenship behaviour mediate the relationship between working environment and organizational performance in the context of gold industry in Saudi Arabia?

4. To which extent can organization citizenship behavior mediate the relationship between employee involvement and organizational performance in the context of gold industry in Saudi Arabia?

5. To which extent can organization citizenship behaviour mediate the relationship between incentives and organizational performance in the context of gold industry in Saudi Arabia?

6. To which extent can organization citizenship behaviour mediate the relationship between employee motivation and organizational performance in the context of gold industry in Saudi Arabia?

\section{Proposed conceptual framework and hypotheses}

After reviewing several theories that dealt with research variables, the researcher relied on social exchange theory to build a conceptual framework, which covers all aspects of the problem in gold industry in Saudi Arabia. This theory has many interpretations according to the orientations of thinkers (Nunkoo, 2016). The social process has a decisive impact on the process of genuine involvement. The social process refers to interaction between employees and leaders as well as the extent or composition of such interaction. The research variables, as shown in the Figure 1, were chosen after reviewing all of the past literature as well as the characteristics of the gold industry in Jeddah, Saudi Arabia. One of the most important challenges facing leaders nowadays is their ability to adapt to a continually changing global environment while at the same time continuing the dynamics of the organization. The style and type of leadership active plays a main role in the successful achievement of their responsibilities and the overall success of their organizations. Leadership manifests itself through different leadership styles (Mildred, 2016). In addition, problem statement provided a detailed and clear explanation of the importance of the 
independent variables that included in this research as well as the extent of their impact on organizational performance by presenting the challenges and obstacles faced by the gold sector in Saudi Arabia. Many studies have shown that the successful organizations are those that care about employee issues, because it is considered as its most important capital investment for managing current and future challenges, so atransformational leaders exhibit certain behaviours to motivate their employees to achieve organizational objectives. Furthermore, continuous performance is required due to its importance for improvement and progress (Shahin et al. 2014). Also, researches especially focus on the scope of organization citizenship behaviours, factors which cause this behaviours, and effects of it on employees and organization (ALHussain, 2011). Transformational leadership is the key to successful change, as the role and importance of leadership have become an important issues due to many convincing reasons such as change is happening everywhere, its speed is increasing, and the future of business organizations is depending on how leaders can lead change (Knies et al., 2016). There is no doubt that an appropriate work environment has contributed to change the behavior of employees through reducing turnover and absence rates leading to organizational stability, increasing organizational performance and improving productivity, enhancing mutual trust and job satisfaction among individuals, and reducing negative conflicts in the organization (Ngugi, 2017). In addition, motivation an internal force that activates, guides, and maintains behaviour over time (Saad, 2018). Furthermore, person's sense of the need to take a step and inspiration to move, energizing goal oriented behavior (Gunawan \& Febrianto, 2014). Moreover, motivation is an external stimuli that encourage employees to improve their performance and production (Cooper, 2017).

Based on the above, this research consists of six major hypotheses, which are:

- The first main hypothesis (H1): Organizational citizenship behaviour will mediate the relationship between transformational leadership behaviour and organiza- tional performance in the Saudi Arabian gold industry.

- The second main hypothesis (H2): Organizational citizenship behaviour will mediate the relationship between psychological ownership and organizational performance in the Saudi Arabian gold industry.

- The third main hypothesis (H3): Organizational citizenship behaviour will mediate the relationship between working environment and organizational performance in the Saudi Arabian gold industry.

- The fourth main hypothesis (H4): Organizational citizenship behaviour will mediate the relationship between employee involvement and organizational performance in the Saudi Arabian gold industry.

- The fifth main hypothesis (H5): Organizational citizenship behaviour will mediate the relationship between incentives and organizational performance in the Saudi Arabian gold industry.

- The sixth main hypothesis (H6): Organizational citizenship behaviour will mediate the relationship between employee motivation and organizational performance in the Saudi Arabian gold industry.

\section{Research methodology}

In this paper, a quantitative research approach was applied through a questionnaire specifically designed to collect primary information from the samples of the study. In this research, the study population consisted of 1160 managers (840 shops and factory) from both first and second administrative levels in gold shops in Jaddah. Accordingly, the research sample size consisted of 250 managers, with a percentage of $21.55 \%$. The questionnaire was filled online on SurveyMonkey website by managers in gold industry, where the number was 273 , 23 were excluded because they contain incomplete information. Finally, 250 questionnaires were analysed with a response rate of $91.58 \%$. In addition, Cronbach alpha coefficient was calculated to measure the questionnaire variables and verify their validity, which means the strength

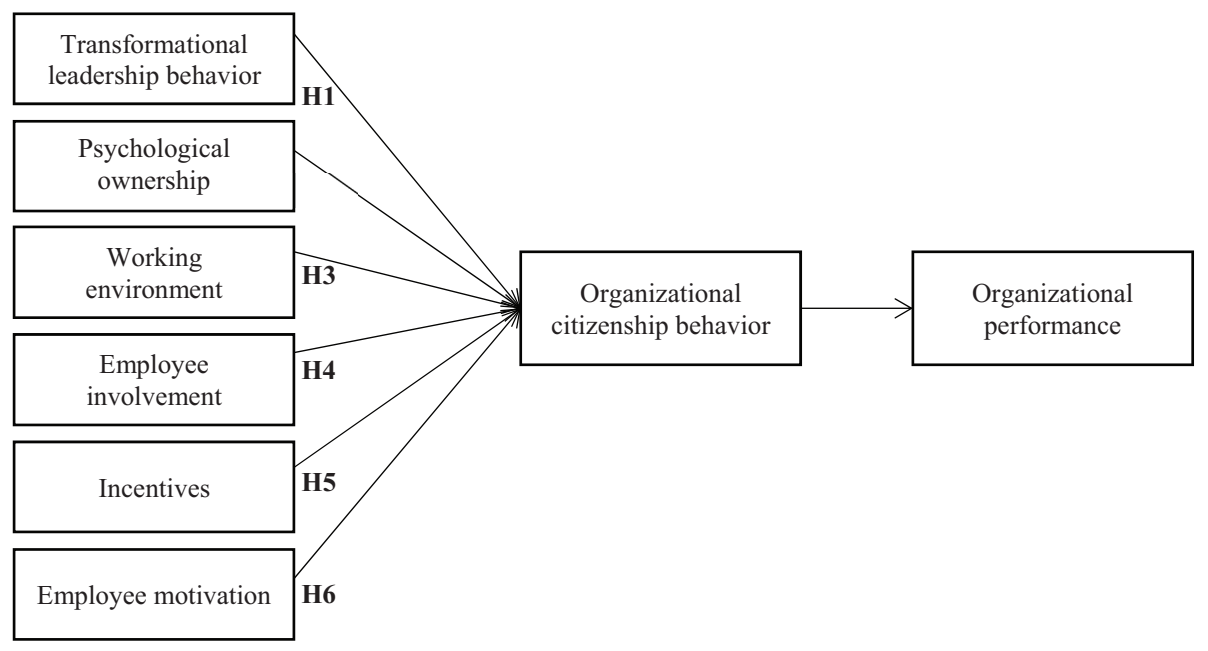

Figure 1. A Proposed conceptual framework 
of the correlation between the measurement paragraphs. In addition, the Alpha coefficient is given with a good estimate of reliability. Although there are no standards for the appropriate alpha values, in practice, alpha that is greater than 60.0 is considered acceptable. The Table 1 shows the Cronbach's alpha values for the study variables, where organizational performance variable obtained the highest value, which reached 0.972 , while work environment variable obtained the lowest value, which reached 0.789 . The questionnaire as a whole obtained a value of 0.972 , which reflects the consistency of all the paragraphs of the questionnaire.

Table 1. Cronbach's Alpha for the questionnaire

\begin{tabular}{|l|c|c|}
\hline \multicolumn{1}{|c|}{ Scale } & $\begin{array}{c}\text { Item } \\
\text { number }\end{array}$ & $\begin{array}{c}\text { Cronbach's } \\
\text { Alpha (\%) }\end{array}$ \\
\hline $\begin{array}{l}\text { Transformational Leadership } \\
\text { Behaviour }\end{array}$ & 6 & 0.790 \\
\hline Psychological Ownership & 5 & 0.792 \\
\hline Working Environment & 5 & 0.789 \\
\hline Employee Involvement & 5 & 0.825 \\
\hline Incentives & 5 & 0.818 \\
\hline Employee Motivation & 5 & 0.825 \\
\hline Organization Citizenship Behaviour & 8 & 0.876 \\
\hline Organizational Performance & 8 & 0.878 \\
\hline Entire Questionnaire & 47 & 0.972 \\
\hline
\end{tabular}

\subsection{Confirmatory factor analysis}

In order to construct research variables model, Structural Equation Modelling (SEM) was employed. The proper selection of methodology depends on the complexity of proposed model, quality of the data, so the researcher was used SEM in order to provide more sophisticated information concerning the significance of the indirect effects. A measure of goodness-of-fit was used using Smart-PLS 3 software. The appropriateness of the structural model is judged by the appropriate measures that extracted, through which the acceptability of the previously assumed relationship is recognized. When there is a good acceptance according to these measures, the model is accurate, the reverse is weak and the model can be rejected. It is clear from the figure 2 that the model has obtained good values for measures of goodness of fit. The figure below explains that the minimum value of the discrepancy, which is a division of Chi2 over the degree of freedom, is 2.425, which reflects a perfect fit. Also, the model has a comparative fit index (CFI), Tucker-Lewis Index (TLI), and normed fit index (NFI) of $0.807,0.792$, and 0.663 respectively, which reflects a perfect fit. Other measures of model fit include the root mean square residual (RMSEA), as the model has a RMSEA of 0.076 , which indicates a reasonable error of approximation. In addition, the model has an Incremental Fit Index (IFI) of 0.809, which indicates a perfect fit. Furthermore, the model has a goodnessof-fit index (GFI) of 0.823 , which indicates a perfect fit.
Finally, the model has an adjusted goodness-of-fit index (AGFI) of 0.911, which indicates a good fit.

\subsection{Testing hypotheses}

PLS_SEM path analysis was used to test the research hypotheses as shown in the figures and tables below. PLS is a robust, flexible and comprehensive technique for examining the relationships between measured variables and underlying structures. In particular, PLS aims to determine the conformity of the theoretical model of the field data, that is, the extent to which the theoretical model is supported by sample data (Mardani et al., 2017).

The first main hypothesis (H1): Organizational citizenship behaviour will mediate the relationship between transformational leadership behaviour and organizational performance in the Saudi Arabian gold industry.

The Table 2 shows that the paths for the indirect effect (OCB <--- TLB and OP <--- OCB) are significant $(\mathrm{P}$-value $<0.05)$. Since the value of indirect path $(0.09 \times 1.25=0.11)$ is larger than the value of direct path $(-0.07)$, the mediation of organizational citizenship behaviour occurs, leading to acceptance of the first main

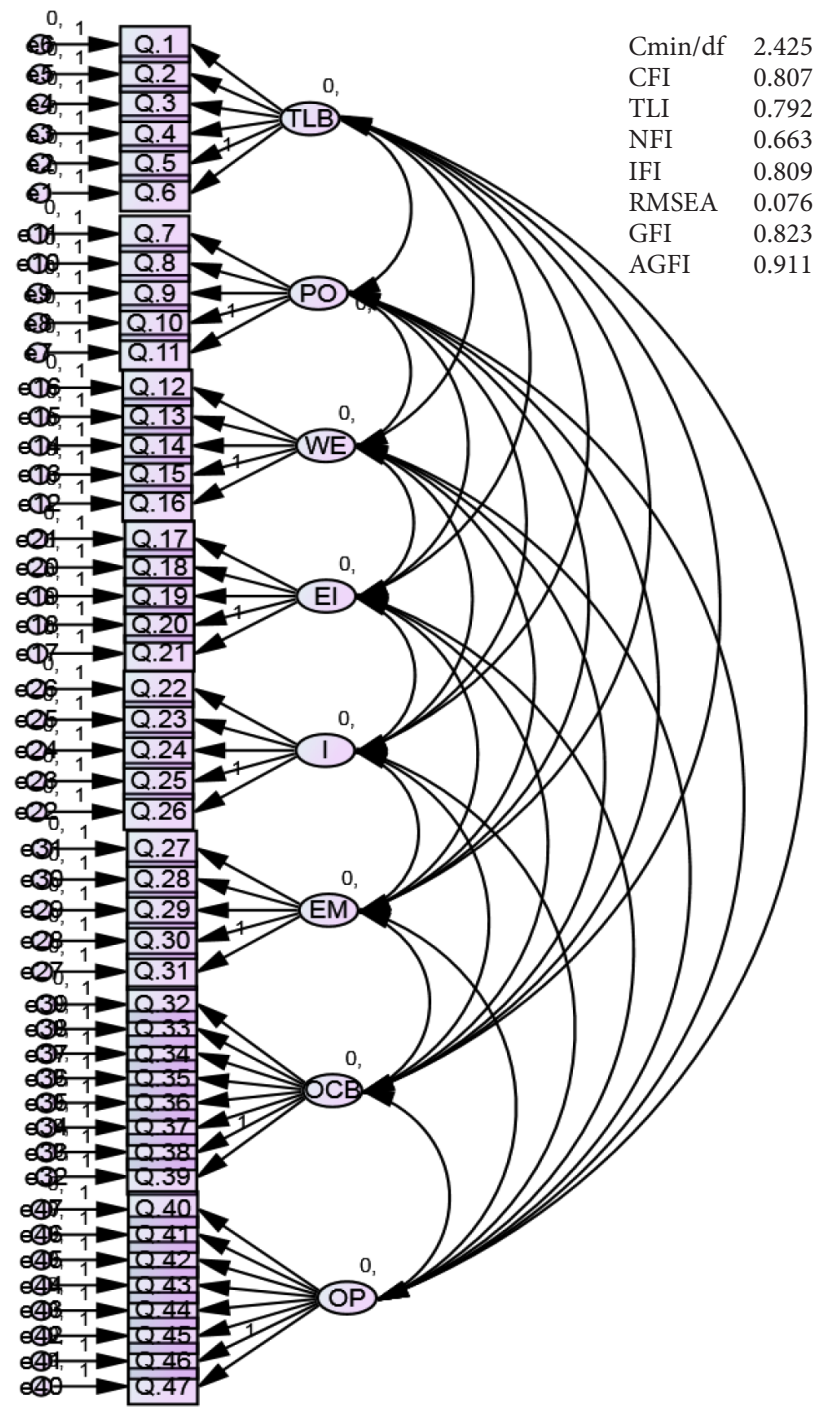

Figure 2. The structural model with Fitness index 
Table 2. The coefficient estimates and P-values - the mediating effect of OCB on the relationship between TLB \& OP

\begin{tabular}{|c|c|c|c|c|c|c|l|}
\hline \multicolumn{2}{|l|}{} & Estimate & S.E. & C.R. & P & \multicolumn{1}{|c|}{ Result } \\
\hline OCB & $<---$ & TLB & .902 & .112 & 8.014 & 0.000 & Significant \\
\hline OP & $<---$ & OCB & 1.249 & .144 & 8.694 & 0.000 & Significant \\
\hline OP & $<---$ & TLB & -.074 & .112 & -.666 & 0.505 & Not Significant \\
\hline
\end{tabular}

hypothesis (H1). Therefore, organizational citizenship behaviour had mediating effect on the relationship between transformational leadership behaviour and organizational performance as shown in the Figure 3. Since the direct effect (OP <--- TLB) is insignificant, type of mediation is complete. Consequently, the researcher concludes that there is a strong positive correlation between organizational citizenship behavior and transformational leadership behavior.

The second main hypothesis (H2): Organizational citizenship behaviour will mediate the relationship between psychological ownership and organizational performance in the Saudi Arabian gold industry.

The Table 3 shows that the paths for the indirect effect (OCB <--- PO and OP <--- OCB) are significant $(\mathrm{P}$-value $<0.05)$. Since the value of indirect path $(0.83 \times 1.15=0.95)$ is larger than the value of direct path (0.04), the mediation of organizational citizenship behaviour occurs, leading to acceptance of the second main hypothesis (H2). Therefore, organizational citizenship behaviour had mediating effect on the relationship between psychological ownership and organizational performance as shown in the Figure 4. Since the direct effect (OP <--- PO) is insignificant, type of mediation is complete. Consequently, the researcher concludes that there is a strong positive correlation between organizational citizenship behavior and psychological ownership.

The third main hypothesis (H3): Organizational citizenship behaviour will mediate the relationship between working environment and organizational performance in the Saudi Arabian gold industry.

As shown in the Table 4, since the path for the indirect effect $(\mathrm{OP}<---\mathrm{OCB})$ is insignificant $(\mathrm{P}$-value > 0.05), no mediation of organizational citizenship behaviour occurs, leading to rejection of the third main hypothesis (H3). Therefore, organizational citizenship behaviour had no mediating effect on the relationship between working environment and organizational performance as shown in the Figure 5.

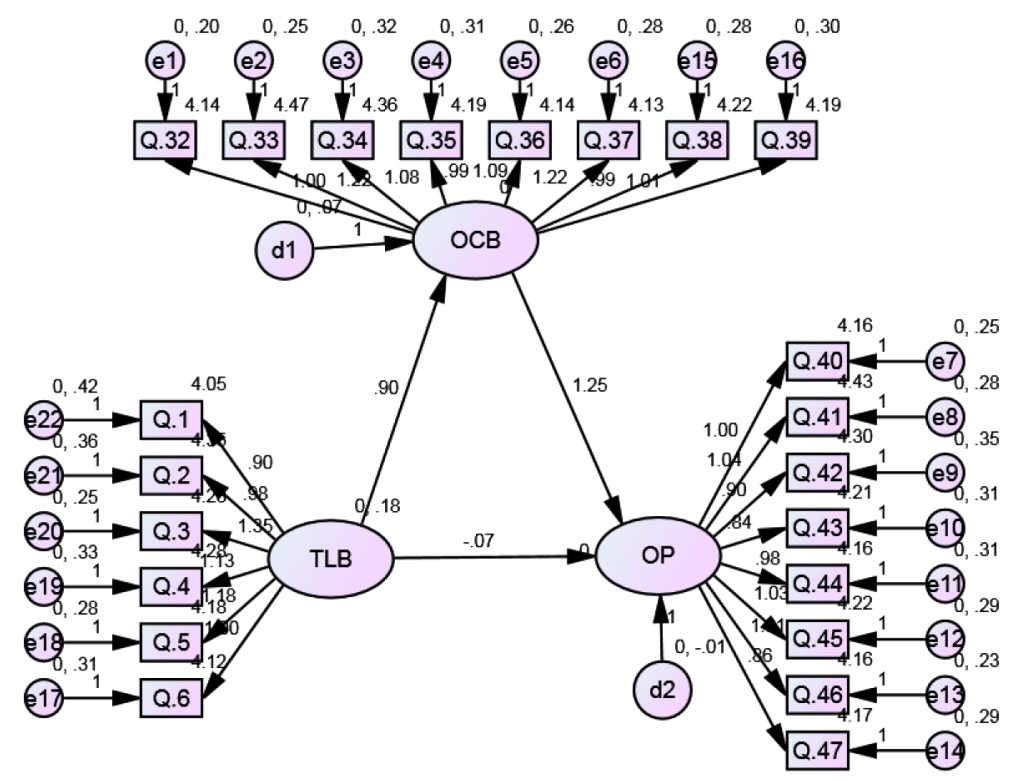

Figure 3. The mediating effect of organizational citizenship behaviour on the relationship between transformational leadership behaviour and organizational performance

Table 3. The coefficient estimates and P-values - the mediating effect of OCB on the relationship between PO \& OP

\begin{tabular}{|c|c|c|c|c|c|c|l|}
\hline \multicolumn{2}{|l}{} & Estimate & S.E. & C.R. & P & \multicolumn{1}{|c|}{ Result } \\
\hline OCB & $<---$ & PO & .828 & .086 & 9.653 & 0.000 & Significant \\
\hline OP & $<---$ & OCB & 1.149 & .207 & 5.557 & 0.000 & Significant \\
\hline OP & $<---$ & PO & .037 & .166 & .225 & 0.822 & Not Significant \\
\hline
\end{tabular}




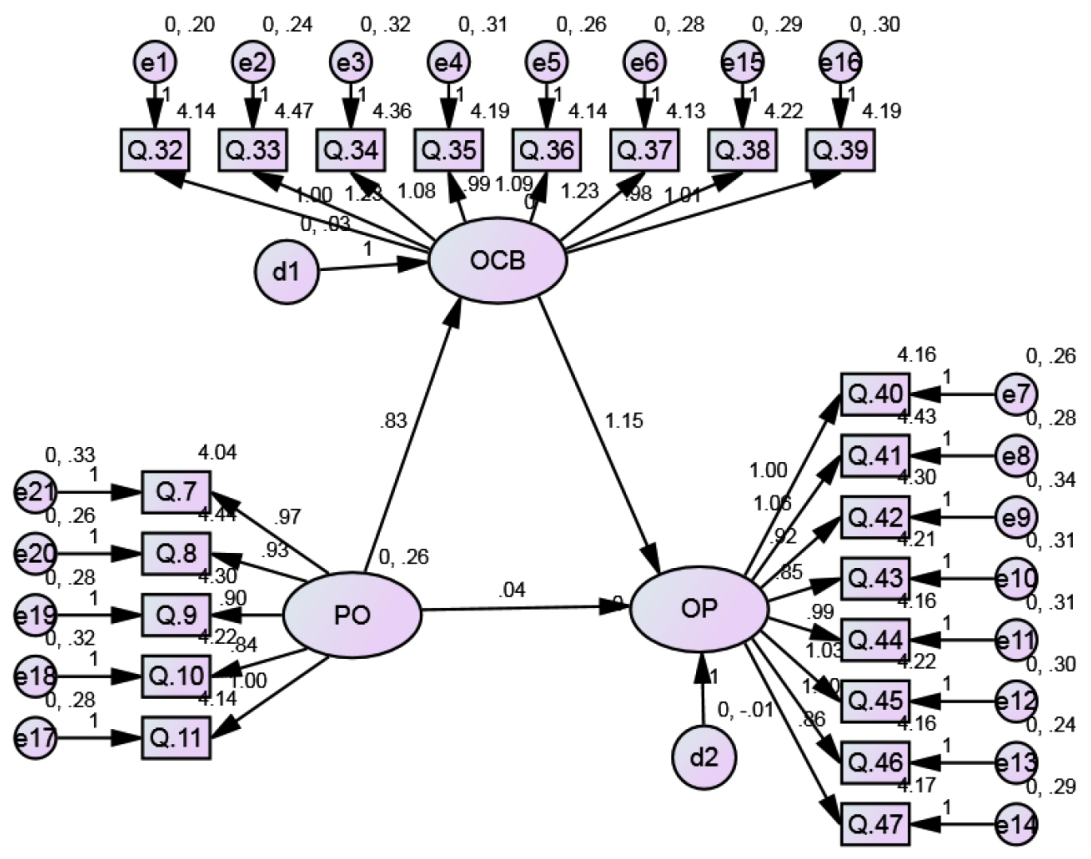

Figure 4. The mediating effect of organizational citizenship behaviour on the relationship between psychological ownership and organizational performance

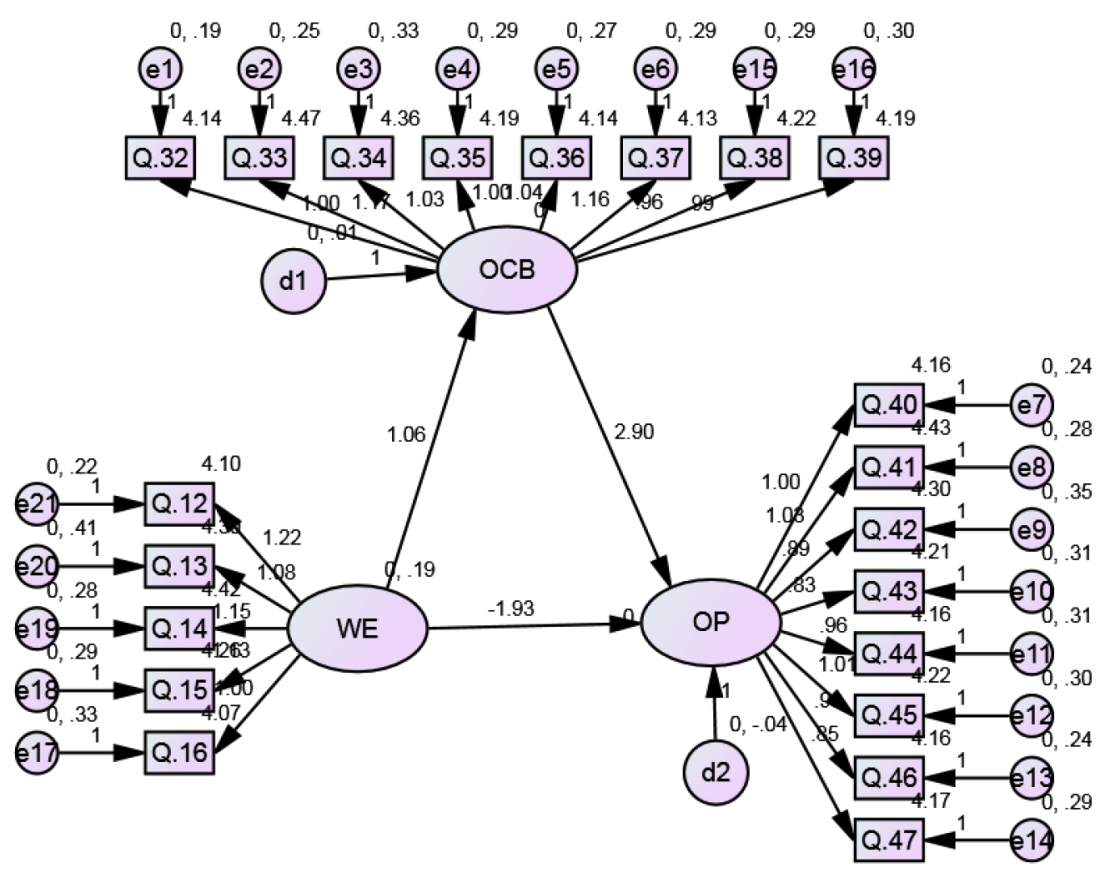

Figure 5. The mediating effect of organizational citizenship behaviour on the relationship between working environment and organizational performance

Table 4. The coefficient estimates and P-values - the mediating effect of OCB on the relationship between WE \& OP

\begin{tabular}{|c|c|c|c|c|c|c|l|}
\hline \multicolumn{2}{|l}{} & Estimate & S.E. & C.R. & P & \multicolumn{1}{|c|}{ Result } \\
\hline OCB & $<---$ & WE & 1.057 & .117 & 9.068 & 0.000 & Significant \\
\hline OP & $<---$ & OCB & 2.904 & 1.579 & 1.838 & 0.066 & Not Significant \\
\hline OP & $<---$ & WE & -1.928 & 1.715 & -1.124 & 0.261 & Not Significant \\
\hline
\end{tabular}


Table 5. The coefficient estimates and P-values - the mediating effect of OCB on the relationship between EI \& OP

\begin{tabular}{|c|c|c|c|c|c|c|l|}
\hline \multicolumn{2}{|l|}{} & Estimate & S.E. & C.R. & P & \multicolumn{1}{|c|}{ Result } \\
\hline OCB & $<---$ & EI & .855 & .085 & 10.084 & 0.000 & Significant \\
\hline OP & $<---$ & OCB & 2.464 & 1.431 & 1.722 & 0.085 & Not Significant \\
\hline OP & $<---$ & EI & -1.123 & 1.243 & -.904 & 0.366 & Not Significant \\
\hline
\end{tabular}

The fourth main hypothesis (H4): Organizational citizenship behaviour will mediate the relationship between employee involvement and organizational performance in the Saudi Arabian gold industry.

As shown in the Table 5, since the path for the indirect effect $(\mathrm{OP}<---\mathrm{OCB})$ is insignificant (P-value > 0.05), no mediation of organizational citizenship behaviour occurs, leading to rejection of the fourth main hypothesis (H4). Therefore, organizational citizenship behaviour had no mediating effect on the relationship between employee involvement and organizational performance as shown in the Figure 6.

The fifth main hypothesis (H5): Organizational citizenship behaviour will mediate the relationship between incentives and organizational performance in the Saudi Arabian gold industry.

As shown in the Table 6, the paths for the indirect effect (OCB <--- I and OP <--- OCB) are significant (P-value <
$0.05)$. Since the value of indirect path $(0.88 \times 1.29=1.14)$ is larger than the value of direct path $(-0.08)$, the mediation of organizational citizenship behaviour occurs, leading to acceptance of the fifth main hypothesis (H5). Therefore, organizational citizenship behaviour had mediating effect on the relationship between incentives and organizational performance as shown in the Figure 7 . Since the direct effect ( $\mathrm{OP}<---\mathrm{I}$ ) is insignificant, type of mediation is complete. Consequently, the researcher concludes that there is a strong positive correlation between organizational citizenship behaviour and incentives.

The sixth main hypothesis (H6): Organizational citizenship behaviour will mediate the relationship between employee motivation and organizational performance in the Saudi Arabian gold industry.

As shown in the Table 7 , the path for the indirect effect $(\mathrm{OP}<---\mathrm{OCB})$ is insignificant $(\mathrm{P}$-value $>0.05)$, no mediation of organizational citizenship behaviour occurs,

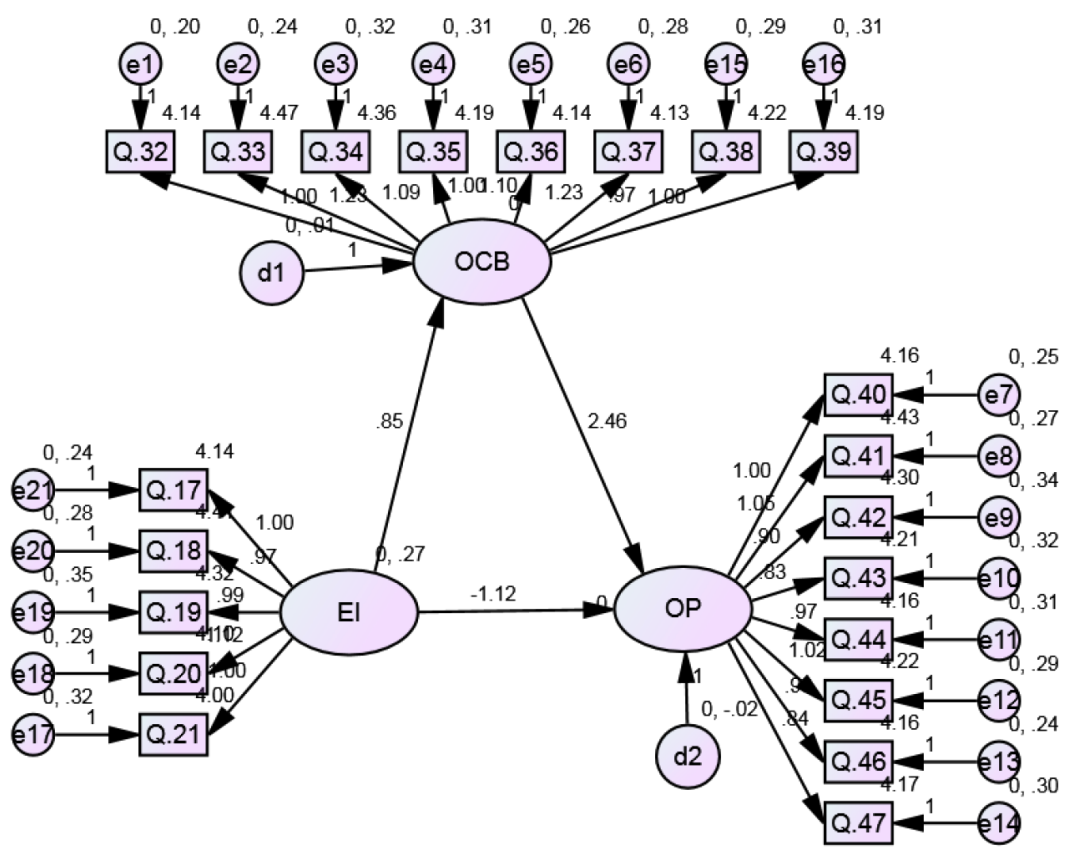

Figure 6. The mediating effect of organizational citizenship behaviour on the relationship between employee involvement and organizational performance

Table 6. The coefficient estimates and P-values - the mediating effect of OCB on the relationship between I \& OP

\begin{tabular}{|c|c|c|c|c|c|c|l|}
\hline \multicolumn{2}{|l|}{} & Estimate & S.E. & C.R. & P & \multicolumn{1}{|c|}{ Result } \\
\hline OCB & $<---$ & I & .875 & .100 & 8.778 & 0.000 & Significant \\
\hline OP & $<--$ & OCB & 1.285 & .241 & 5.331 & 0.000 & Significant \\
\hline OP & $<---$ & I & -.078 & .205 & -.380 & 0.704 & Not Significant \\
\hline
\end{tabular}




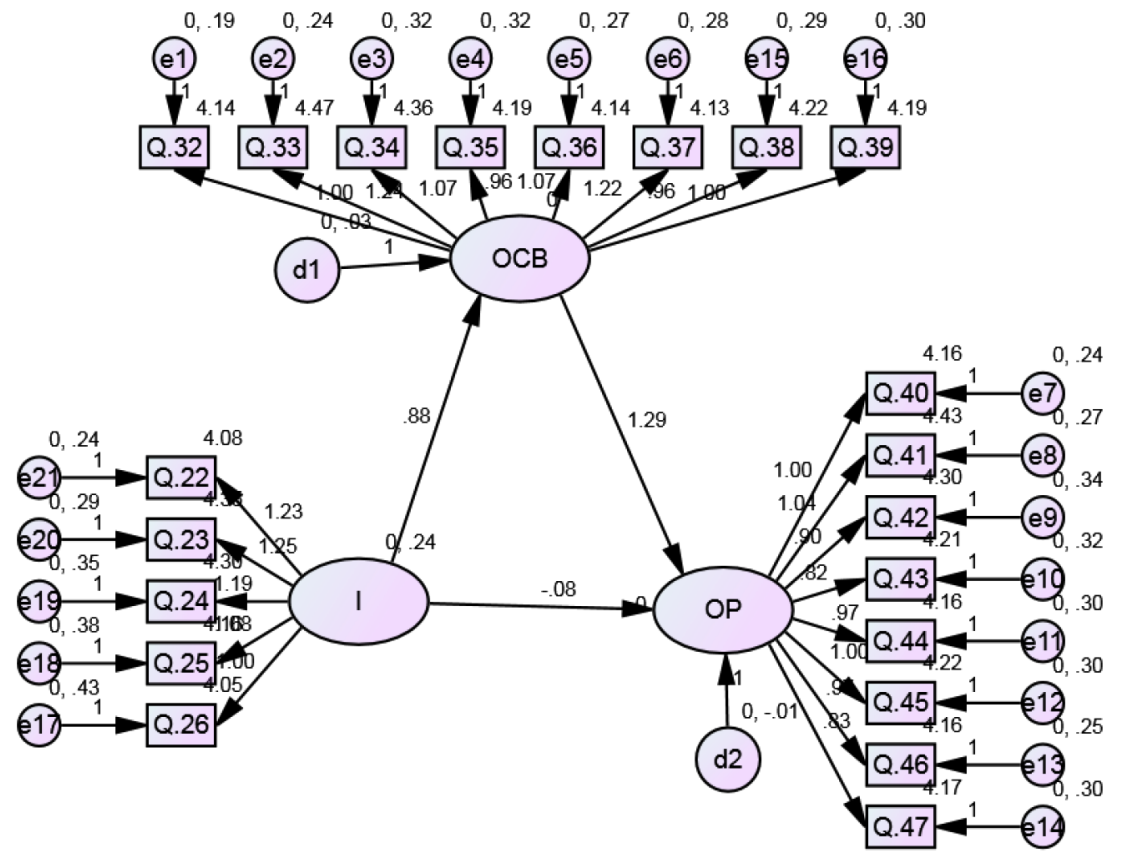

Figure 7. The mediating effect of organizational citizenship behaviour on the relationship between incentives and organizational performance

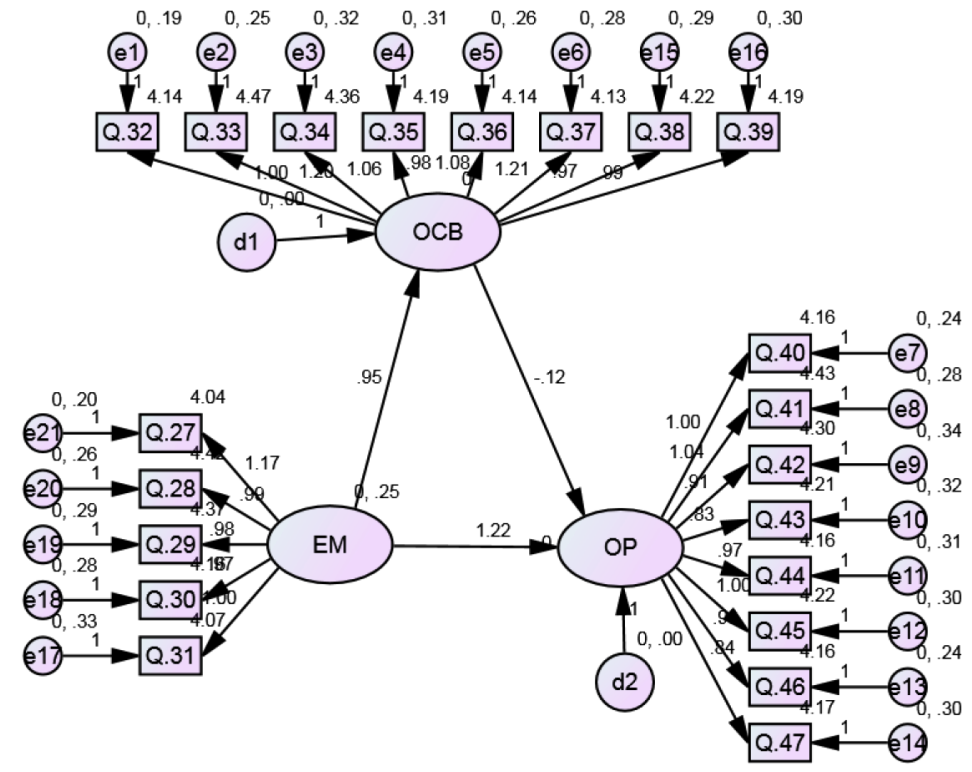

Figure 8. The mediating effect of organizational citizenship behaviour on the relationship between employee motivation and organizational performance

Table 7. The coefficient estimates and P-values - the mediating effect of OCB on the relationship between EM \& OP

\begin{tabular}{|c|c|c|c|c|c|c|c|}
\hline \multicolumn{2}{|l|}{} & Estimate & S.E. & C.R. & P & Result \\
\hline OCB & $<---$ & EM & .946 & .093 & 10.137 & 0.000 & Significant \\
\hline OP & $<--$ & OCB & -.118 & 1.576 & -.075 & 0.940 & Not Significant \\
\hline OP & $<---$ & EM & 1.217 & 1.472 & .827 & 0.408 & Not Significant \\
\hline
\end{tabular}


leading to rejection of the sixth main hypothesis (H6). Therefore, organizational citizenship behaviour had no mediating effect on the relationship between employee motivation and organizational performance as shown in the Figure 8.

\section{Discussion}

The results showed that organization citizenship behaviour mediates the relationship between transformational leadership behaviour and organizational performance. This results is consistent with Majeed et al. (2017), which have revealed a strong relationship between transformational leadership and organizational citizenship behaviour, as the transformational leaders always motivate their employees to do more than expected by acting as role models for them, respecting them and paying attention to their needs, thus increasing the level of trust of their employees, which improve their performance. Since characteristics of transformational leader are one of the key factors for the organization's success or failure. It influences the behaviours of employees in their formal and informal roles. The behaviour of an informal role is not within the official job description within the organization but is carried out voluntarily by employees, this behaviour is an important factor for the organization to achieve its objectives and competitive advantage, which enhance organizational performance (Veliu et al., 2017). Here the role of transformational leaders is clear who must be aware of employees' behaviours with a view to directing them to serve the organization's performance and objectives. In other words, transformational leadership is characterized by its ability to create an effective behaviour that increases the self-efficacy of employees in order to achieve organizational performance (Soane et al., 2015).

The results showed that organization citizenship behaviour mediates the relationship between psychological ownership and organizational performance. This results is consistent with Peng and Pierce (2015), which illustrated that organizational citizenship behavior followed by the employees is due to the employees' sense of responsibility towards the company, which makes them behave consciously, courteously and altruistically. In general, the researcher believes that a sense of psychological ownership is prevalent in Saudi Arabia. When employees feel a sense of ownership, they feel a psychological attachment to the organization, and this feeling is rooted in their organizational citizenship behavior. Psychological ownership and organizational citizenship behavior are so closely linked and interrelated to an extent that cannot be separated. Accordingly, a sense of psychological ownership leads to many positive employees' behaviors, which will certainly improve organizational performance (Pan et al., 2014).

The results showed that organization citizenship behaviour has no mediating effect on the relationship between the working environment and organizational performance. This result can be traced back to negative working environment that may be the reason for the decline in the performance of the organization, which may cause employees to leave. This contradicts with organizational citizenship behavior concept, which depended heavily on employees' willingness to work in unsuitable working conditions without complaint (Massoudi \& Hamdi, 2017). Some studies have revealed that the characteristics of the work environment influence organizational citizenship behaviour rather than the personality of employees. The working environment is the main means of improving performance and increasing employee productivity, which reflects organizational performance. The researcher believes that managers suffer from poor ability to manage employees' emotions in the workplace, and thus reduces productivity, creativity and the desire to find appropriate solutions to work problems, which negatively affects organizational performance (Bushiri, 2014). There is no doubt that bad condition in the work environment, as well as psychological stress on employees, affect employees in terms of their desire to work. In order to create a stimulating and motivating work environment, new management visions should take into consideration the problems and concerns of employees and communication in the workplace, which help improve employee organizational citizenship behaviour (Luu, 2017). The reason behind this result may be due to that the working conditions represent the environment in which the employee lives daily, so the specificity of these conditions represents a clear dividing line between the exercises of official functions only or the exercises of additional functions and roles. The inability of the organization's culture and values to provide an effective and stimulating work environment reduces the chances of exercising organizational citizenship behaviours because this affects the performance of employees and their positive behaviours, which negatively affect the overall performance of the organization (Raziq \& Maulabakhsh, 2015).

The results showed that organization citizenship behaviour has no mediating effect on the relationship between employee involvement and organizational performance. This result can be attributed to the tendency of managers to make decisions without reference to employees, which is contrary to the concept of organizational citizenship behaviour, which depends on the interaction between employees and management within the organization, leading to increased overall results achieved. The lack of employees' participation in decision-making makes them frustrated, as organizations should leave part of the behaviours and responsibilities for employees, thus allowing them to cope with unforeseen situations that require creative action (Lazauskaite-Zabielske et al., 2018). Organizations are always in urgent need to their employees who do more than their normal duties, which requires the presence of staff who exhibit a high level of organizational citizenship behaviour. Organizations where work is limited to the performance of each individual's work only or do not allow staff to participate in decision-making are doomed to failure. So employee involvement can be 
achieved not only through formal roles but also with the development of organizational citizenship behaviour (Chandani et al., 2016). The desire to participate more than job duties is a major element of organizations' activities. Although this behaviour goes beyond mere role-playing, however, it does not directly conflict with the requirements of the job. It also improves organizational performance. As organizations in which employee involvement is prohibited or restricted, since these organizations suffer from poor performance (Mustafa et al., 2016). This behaviour is the primary determinant of the desire to perform a specific task; that is, a lack of organizational citizenship is a reflection of the weakness of employee involvement in decision making. The researcher believes that the reason for this result was that the managers' view of the most effective workers is not limited to those producers, but to employees who are able to increase the performance of others around them by helping or dealing with a sportsmanship and consciousness. By identifying this behaviour it can be judged that organizational citizenship behaviour contributes to the improvement of organizational performance, because this behaviour provides an effective means of managing the affairs of employees in the work environment and increasing positive results (Jha, 2014).

The results showed that organization citizenship behaviour mediates the relationship between incentives and organizational performance. This result is consistent with Alkahtani (2015), which explained that incentives are used to influence the motivational forces within employees, and direct them in a way that allows them to continue their activity in a certain way, in order to achieve the goals set by the organization. In the light of the results of this study, it can be concluded that employee motivation is a process organized by organizations aimed at maintaining employees' continuity and encouragement in their work, but this is coupled with a specific system for the use of incentives. Such a system should be established on the basis of scientific findings to achieve employees' satisfaction, and thus improve organizational performance (Mamdani \& Minhaj, 2016). The researcher believes that organizational citizenship is selective behaviour that involves performing more activities than required of the individual and obeying and respecting the company's rules, regulations and procedures. As the employee is not rewarded through formal incentive systems in the organization. There is no doubt that incentives will inevitably increase organizational citizenship behaviour among employees and push them to play additional roles, which will have a positive impact on organizational (Mokhniuk, 2016).

The results showed that organization citizenship behaviour has no mediating effect on the relationship between employee motivation and organizational performance. This finding can be attributed to the fact that employee motivation can be adopted by monitoring employees behaviour, their adherence to the organization's policies and systems, and performance rates that achieve, which in turn may put pressure on employees, which makes employees adhere to the limits of the duties assigned to them, and this is contrary to the concept of organizational citizenship behaviour (Nabi et al., 2017). Organizations can do a number of things that affect the feeling and desire of employees to perform organizational citizenship behaviour, and take appropriate steps to enhance their abilities and skills to demonstrate it. Employees may not be able to show some regulatory citizenship behaviour if they do not have appropriate motivational incentives to do so. As providing an appropriate working environment, changing some of the basics of employees' performance, and the conditions in which they work, help to strengthen organizational citizenship behaviour among employees (Abusharbeh \& Nazzal, 2018). In addition, one of the most important things that weaken employee organizational citizenship behaviour is to reward the bad employee, as some organizations promote some employees only for their skill in flattery, not because of their outstanding performance and achievements. If employees are not stimulated fairly, organizational citizenship behaviour and organizational performance become doubtful. So management must understand employee motivation, so incentive system should be appropriate and satisfactory for those needs, which improve their performance (Kumari \& Thapliyal, 2017).

\section{Conclusions}

This paper mainly aims at investigating the mediating effect of organizational citizenship behaviour in the relationship between transformational leadership behaviour and organizational performance as well as the mediating effect of organizational citizenship behaviour in the relationship between psychological ownership, working environment, employee involvement, incentives, and employee motivation, and organizational performance. To achieve the objectives of the study, quantitative research approach was applied through a questionnaire specifically designed to collect primary information from the samples of the study, which consisted of (250) managers in gold shops in Jaddah. The results showed that organization citizenship behaviour mediates the relationship between transformational leadership behaviour, psychological ownership and incentives, and organizational performance in the Saudi Arabian gold industry. Also, organization citizenship behaviour has no mediating effect on the relationship between working environment, employee involvement, employee motivation, and organizational performance in the Saudi Arabian gold industry. At the end of this study, the researcher recommended the need to encouraging the practice of organizational citizenship behaviours by developing a set of special regulations and instructions, and consider organizational citizenship behaviours as one of the important criteria in the annual performance appraisal models for employees. It is noteworthy that entrenching these behaviours in the culture of the organization does not require a great effort or high costs, it only needs to incorporate these behaviours into the business plan and the organization's strategy in such a way that it benefits the individual and the business at large. 
The outcomes of this research may be the starting point for many future research that are interested in the subject of transformational leadership and its impact on organizational performance in Saudi Arabia. Also, many variables that have not been discussed in this research can be considered, which have a significant impact on organizational performance such as employee commitment and loyalty. Moreover, future researchers can benefit from the idea of this study by applying it to other sectors such as telecommunications, banks, etc. Moreover, future researchers can use other methods such as the qualitative approach and case study, then making a comparison between the results. Future research can consider bigger sample from different countries.

This research was based on a wide range of factors, which contributed to the importance of the validity of the results of this research. However, future research can focus on a particular aspect of this research such as the effect of psychological ownership on functional commitment in the gold sector in Saudi Arabia, the effect of transformational leadership on job security and psychological withdrawal in the gold sector in Saudi Arabia, the effect of a sense of job-based psychological ownership on other variables such as organizational culture, organizational climate. Finally, this study may benefit researchers in the industrial field and encourage them to conduct new studies on transformational leadership theory, and its impact on many variables, such as job satisfaction, organizational loyalty, performance improvement, subordinate ethics, and other variables that will improve organizational performance.

\section{References}

Abusharbeh, M. T., \& Nazzal, H. H. (2018). The impact of motivations on employees performance: case study from Palestinian commercial banks. International Business Research, 11(4), 142. https://doi.org/10.5539/ibr.v11n4p142

Agbozo, G. K., Owusu, I. S., Hoedoafia, M. A., \& Atakorah, Y. B. (2017). The effect of work environment on job satisfaction: evidence from the banking sector in Ghana. Journal of $\mathrm{Hu}$ man Resource Management, 5(1), 12-18.

https://doi.org/10.11648/j.jhrm.20170501.12

Ahmad, I., \& Zafar, M. A. (2018). Impact of psychological contract fulfillment on organizational citizenship behavior: Mediating role of perceived organizational support. International Journal of Contemporary Hospitality Management, 30(2), 1001-1015. https://doi.org/10.1108/IJCHM-12-2016-0659

Alfandi, A. M., \& Alkahsawneh, M. S. (2014). The role of the incentives and reward system in enhancing employee's performance "A case of Jordanian travel and tourism institutions". International Journal of Academic Research in Business and Social Sciences, 4(4), 326.

https://doi.org/10.6007/IJARBSS/v4-i4/788

ALHussain, A. Z. (2011). Barriers to knowledge management in Saudi Arabia. The George Washington University.

Ali, A. (2009). Business and management environment in Saudi Arabia: challenges and opportunities for multinational corporations. Routledge.

https://doi.org/10.4324/9780203883518
Alkahtani, A. (2015). Organizational citizenship behavior (OCB) and rewards. International Business Research, 8(4), 210. https://doi.org/10.5539/ibr.v8n4p210

AlKindy, A. M., Shah, I. M., \& Jusoh, A. (2016). The impact of transformational leadership behaviors on work performance of omani civil service agencies. Asian Social Science, 12(3), 152. https://doi.org/10.5539/ass.v12n3p152

Almarhoon, A., Bin Mohdnoor, K., Abdalla, M., \& Musbah, A. (2017). Effect of motivation on employees' performance and employees' commitment. International Journal of Management and Applied Science, 3(9), 39-43.

Alqatawenah, A. S. (2018). Transformational leadership style and its relationship with change management. Business: Theory and Practice, 19, 17. https://doi.org/10.3846/btp.2018.03

Amoatemaa, A. S., \& Kyeremeh, D. D. (2016). Making employee recognition a tool for achieving improved performance: implication for Ghanaian universities. Journal of Education and Practice, 7(34), 46-52.

Bari, N., Arif, U., \& Shoaib, A. (2013). Impact of non-financial rewards on employee attitude and performance in the workplace. A case study of business institutes of Karachi. International Journal of Sciencetific and Engineering Research, Pakistan, 4(7), 2554-2559.

Brandt, T., \& Laiho, M. (2013). Gender and personality in transformational leadership context: An examination of leader and subordinate perspectives. Leadership \& Organization Development Journal, 34(1), 44-66. https://doi.org/10.1108/01437731311289965

Bushiri, C. P. (2014). The impact of working environment on employees' performance, the case of Institute of Finance Management in Dar es Salaam [Doctoral dissertation, The Open University of Tanzania].

Campbell Pickford, H., Joy, G., \& Roll, K. (2016). Psychological ownership: effects and applications. Saïd Business School RP 2016-32. https://doi.org/10.2139/ssrn.2893092

Campbell, J. W., Lee, H., \& Im, T. (2016). At the expense of others: altruistic helping behaviour, performance management and transformational leadership. Public Management Review, 18(6), 795-818.

https://doi.org/10.1080/14719037.2015.1045018

Chandani, A., Mehta, M., Mall, A., \& Khokhar, V. (2016). Employee engagement: A review paper on factors affecting employee engagement. Indian Journal of Science and Technology, 9(15), 1-7. https://doi.org/10.17485/ijst/2016/v9i15/92145

Cheema, J. R., \& Asrar-ul-Haq, M. (2017). Effects of staff participation, morale, and shortage on organisational performance: An international survey. Issues in Educational Research, 27(4), 677.

Chepkemoi, J. (2018). Effect of incentives on employee performance At Kenya forest service Uasin Gishu county. IOSR Journal of Business and Management (IOSR-JBM), 20(3), 26-32.

Chong, V. K., \& Law, M. B. (2016). The effect of a budget-based incentive compensation scheme on job performance: the mediating role of trust-in-supervisor and organizational commitment. Journal of Accounting \& Organizational Change, 12(4), 590-613. https://doi.org/10.1108/JAOC-02-2015-0024

Cichorzewska, M., \& Rakowska, A. (2017). Organizational citizenship behavior of Polish and Ukrainian civil servants - a comparative study. In Management Challenges in a Network Economy: Proceedings of the MakeLearn and TIIM International Conference 2017 (pp. 393-394). ToKnowPress.

Cooper, V. P. (2017). The impact of motivation, festival attachment, place attachment, and psychological ownership on volunteerism: Understanding the Traverse City Film Festival from the 
volunteer perspective [Master thesis, Iowa State University].

Devi, S. (2017). Impact of employee engagement on organizational performance: A study of select private sector banks. International Journal of Commerce and Management Research, $10-13$.

Dinka, D. D. (2018). Organizational citizenship behaviour and employees' performance assessment: the case of Dire Dawa University. American Journal of Theoretical and Applied Business, 4(1), 15. https://doi.org/10.11648/j.ajtab.20180401.13

Dobre, O. I. (2013). Employee motivation and organizational performance. Review of Applied Socio-Economic Research, 5(1).

Fogec, M. (2017). The experience of psychological ownership of the non-profit organization: Can it be predicted by self-investment and intimate knowledge of the non-profit organization and does it influence future donating behaviour and word of mouth? [Master's thesis, Faculty of Social and Behavioral Sciences, Leiden University].

Guan, X., \& Frenkel, S. (2018). How HR practice, work engagement and job crafting influence employee performance. Chinese Management Studies, 12(3), 591-607.

https://doi.org/10.1108/CMS-11-2017-0328

Gunawan, R., \& Febrianto, H. (2014). The impact of monetary and non-monetary incentives on employees' motivation in PT XYZ'S finance function in Surabaya. iBuss Management, 2(2)

Hemaloshinee, V., \& Nomahaza, M. (2017). Organizational citizenship behavior in hospitality industry: Bridging challenges, benefits and contribution. International Journal of Human Capital in Urban Management, 2(3), 243-250.

Huang, L. C., Ahlstrom, D., Lee, A. Y. P., Chen, S. Y., \& Hsieh, M. J. (2016). High performance work systems, employee well-being, and job involvement: An empirical study. Personnel Review, 45(2), 296-314.

https://doi.org/10.1108/PR-09-2014-0201

Jehanzeb, K., Rasheed, M. F., \& Rasheed, A. (2012). Impact of rewards and motivation on job satisfaction in banking sector of Saudi Arabia. International Journal of Business and Social Science, 3(21).

Jha, S. (2014). Transformational leadership and psychological empowerment: Determinants of organizational citizenship behavior. South Asian Journal of Global Business Research, 3(1), 18-35. https://doi.org/10.1108/SAJGBR-04-2012-0036

Jun, S. Y. (2017). Mediating effect of social capital between transformational leadership behavior and organizational citizenship behavior in hospital nurses. Journal of Korean Academy of Nursing Administration, 23(5), 558-566.

https://doi.org/10.11111/jkana.2017.23.5.558

Kazimoto, P. (2016). Employee engagement and organizational performance of retails enterprises. American Journal of Industrial and Business Management, 6(04), 516.

https://doi.org/10.4236/ajibm.2016.64047

Khosravizadeh, O., Vatankhah, S., Alirezaei, S., Doosty, F., Mousavi Esfahani, H., \& Rahimi, M. (2017). Organizational citizenship behavior and its relationship with psychological capital: a survey of hospital staffs. Evidence Based Health Policy, Management and Economics, 1(1), 24-31.

Klotz, A. C., Bolino, M. C., Song, H., \& Stornelli, J. (2018). Examining the nature, causes, and consequences of profiles of organizational citizenship behavior. Journal of Organizational Behavior, 39(5), 629-647. https://doi.org/10.1002/job.2259

Knies, E., Jacobsen, C., \& Tummers, L. G. (2016). Leadership and organizational performance: State of the art and research agenda. In J. Storey, J. L. Denis, J. Hartley, \& P. 't Hart (Eds.), Routledge companion to leadership (pp. 404-418). Routledge.
Kumari, P., \& Thapliyal, S. (2017). Studying the impact of organizational citizenship behavior on organizational effectiveness. Human Resource Management, 4(1), 9-21.

Kurose, C. (2013). Motivation, behavior and perfomance in the workplace. George Washington University.

Kvitne, M. B. (2017). Development of organizational citizenship behavior and the effect of psychological contract fulfillment [Master's thesis, University of Oslo].

Lazauskaite-Zabielske, J., Urbanaviciute, I., \& Rekasiute Balsiene, R. (2018). From psychosocial working environment to good performance: the role of work engagement. Baltic Journal of Management, 13(2), 236-249.

https://doi.org/10.1108/BJM-10-2017-0317

Liu, F., Chow, I. H. S., Xiao, D., \& Huang, M. (2017). Crosslevel effects of HRM bundle on employee well-being and job performance: The mediating role of psychological ownership. Chinese Management Studies, 11(3), 520-537. https://doi.org/10.1108/CMS-03-2017-0065

Luu, T. T. (2017). CSR and organizational citizenship behavior for the environment in hotel industry: The moderating roles of corporate entrepreneurship and employee attachment style. International Journal of Contemporary Hospitality Management, 29(11), 2867-2900.

https://doi.org/10.1108/IJCHM-02-2016-0080

Majeed, N., Ramayah, T., Mustamil, N., Nazri, M., \& Jamshed, S. (2017). Transformational leadership and organizational citizenship behavior: Modeling emotional intelligence as mediator. Management \& Marketing, 12(4), 571-590.

https://doi.org/10.1515/mmcks-2017-0034

Mamdani, K. F., \& Minhaj, S. (2016). Effects of motivational incentives on employees' performance: A case study of banks of Karachi, Pakistan. South East Asia Journal of Contemporary Business, Economics and Law, 9(2), 32-39.

Mardani, A., Streimikiene, D., Zavadskas, E. K., Cavalaro, F., Nilashi, M., Jusoh, A., \& Zare, H. (2017). Application of Structural Equation Modeling (SEM) to solve environmental sustainability problems: A comprehensive review and metaanalysis. Sustainability, 9(10), 1814.

https://doi.org/10.3390/su9101814

Massoudi, A. H., \& Hamdi, S. S. A. (2017). The consequence of work environment on employees productivity. Journal of Business and Management, 1(3), 35-42. https://doi.org/10.9790/487X-1901033542

Mildred, A. K. (2016). Effect of employee involvement on job performance at the kenya medical research institute (centre for global health research) kisumu [Doctoral dissertation, School of Business, University of Nairobi].

Mokhniuk, A. M. (2016). The impact of monetary rewards on the motivation of employees. Roczniki Ekonomiczne Kujawsko-Pomorskiej Szkoły Wyższej w Bydgoszczy, (9), 336-346.

Mustafa, M., Martin, L., \& Hughes, M. (2016). Psychological ownership, job satisfaction, and middle manager entrepreneurial behavior. Journal of Leadership \& Organizational Studies, 23(3), 272-287. https://doi.org/10.1177/1548051815627360

Muthike, C. (2016). The impact of employee engagement on organization performance: a case of Pact, Nairobi [Doctoral dissertation, United States International University-Africa].

Nabi, M. N., Islam, M., Dip, T. M., \& Hassain, A. A. (2017). Impact of motivation on employee performances: a case study of Karmasangsthan bank Limited, Bangladesh. International Journal of Business and Management, 5(4), 57-78.

Ngugi, J. (2017). Role of working conditions on organizational citizenship behaviour in the banking industry: a survey of Barclays bank in North rift region. IOSR Journal of Business 
and Management (IOSR-JBM), 19(6), 23-37.

https://doi.org/10.9790/487X-1906013237

Nunkoo, R. (2016). Toward a more comprehensive use of social exchange theory to study residents' attitudes to tourism. Procedia Economics and Finance, 39, 588-596. https://doi.org/10.1016/S2212-5671(16)30303-3

Osisioma, H. E., Osisioma, B. C., \& Chukwuemeka, E. E. (2012). Developing a conflict management model for the Nigerian executive. Singaporean Journal of Business, Economics and Management Studies, 51(1103), 1-19. https://doi.org/10.12816/0003730

Pan, X. F., Qin, Q., \& Gao, F. (2014). Psychological ownership, organization-based self-esteem and positive organizational behaviors. Chinese Management Studies, 8(1), 127-148. https://doi.org/10.1108/CMS-04-2014-0088

Park, R. (2016). The roles of OCB and automation in the relationship between job autonomy and organizational performance: a moderated mediation model. The International Journal of Human Resource Management, 29(6), 1-18. https://doi.org/10.1080/09585192.2016.1180315

Pekaar, K. A., van der Linden, D., Bakker, A. B., \& Born, M. P. (2017). Emotional intelligence and job performance: The role of enactment and focus on others' emotions. Human Performance, 30(2-3), 135-153.

https://doi.org/10.1080/08959285.2017.1332630

Peng, H., \& Pierce, J. (2015). Job-and organization-based psychological ownership: Relationship and outcomes. Journal of Managerial Psychology, 30(2), 151-168. https://doi.org/10.1108/JMP-07-2012-0201

Potdar, B., Guthrie, J., Gnoth, J., \& Garry, T. (2018). The role of psychological ownership in shoplifting prevention: An exploratory study. Journal of Retailing and Consumer Services, 44, 253-265. https://doi.org/10.1016/j.jretconser.2018.07.015

Prabhakar, A. (2016). Analysis of high job satisfaction relationship with employee loyalty in context to workplace environment. IJAR, 2(4), 640-643.

PratimaSarangi, D., \& Nayak, B. (2018). Employee engagement and its impact on organizational success - a study in manufacturing company, India. OSR Journal of Business and Management (IOSR-JBM), 18(4), 52-57.

Rahmati, A., \& Mohebi, M. D. (2016). Relationship between emotional intelligence and job satisfaction of primary health care providers (behvarz). Electronic Journal of Biology, 13(1), $1-5$.

Raja, U., Sheikh, R. A., Abbas, M., \& Bouckenooghe, D. (2018). Do procedures really matter when rewards are more important? A Pakistani perspective on the effects of distributive and procedural justice on employee behaviors. Revue Européenne de Psychologie Appliquée, 68(2), 79-88.

https://doi.org/10.1016/j.erap.2018.03.001
Raziq, A., \& Maulabakhsh, R. (2015). Impact of working environment on job satisfaction. Procedia Economics and Finance, 23, 717-725. https://doi.org/10.1016/S2212-5671(15)00524-9

Robescu, O., \& Iancu, A. G. (2016). The effects of motivation on employees performance in organizations. Valahian Journal of Economic Studies, 7(2), 49-56. https://doi.org/10.1515/vjes-2016-0006

Ruganzi, D. (2017). Effect of Employee engagement on organizational performance: Case of African Evangelistic Enterprise [Doctoral dissertation, University of Rwanda].

Saad, D. (2018). Impact of employee motivation on work performance. International Journal of Scientific and Research Publications, 8(3), 295-308. https://doi.org/10.29322/IJSRP.8.3.2018.p7544

Saudi Mining \& Minerals. (2015). http://www.alsarabia.com/ news/Saudi-Mining--Minerals-2015_500

Shahin, A., Shabani Naftchali, J., \& Khazaei Pool, J. (2014). Developing a model for the influence of perceived organizational climate on organizational citizenship behaviour and organizational performance based on balanced score card. International Journal of Productivity and Performance Management, 63(3), 290-307. https://doi.org/10.1108/IJPPM-03-2013-0044

Shanker, M. (2018). Organizational citizenship behavior in relation to employees' intention to stay in Indian organizations. Business Process Management Journal, 24(3). https://doi.org/10.1108/BPMJ-02-2018-0048

Soane, E., Butler, C., \& Stanton, E. (2015). Followers' personality, transformational leadership and performance. Sport, Business and Management: An International Journal, 5(1), 65-78. https://doi.org/10.1108/SBM-09-2011-0074

Tufail, M. S., Muneer, S., \& Manzoor, M. (2017). How organizational rewards and organizational justice affect the organizational citizenship behavior and counterproductive work behavior: analysis of Pakistan service industries. City University Research Journal Special Issue: AIC, Malaysia, 171-182.

Veliu, L., Manxhari, M., Demiri, V., \& Jahaj, L. (2017). The influence of leadership styles on employee's performance. Management (16487974), 31(2).

https://doi.org/10.33107/ubt-ic.2017.262

World Gold Council, (WGC). (2011). New research suggests higher allocations to gold could benefit portfolios in both inflationary and deflationary scenarios. World Gold Council and Oxford Economics, 11th July, London.

World Gold Council, (WGC). (2014). http://www.gold.org/news-and-events 